ISSN 1678-3921

Journal homepage: www.embrapa.br/pab

For manuscript submission and journal contents, access: www.scielo.br/pab
Sérgio Bertelli Pflanzer ${ }^{(1 凶)}$, Carolina Lugnani Gomes ${ }^{(2)}$ and Pedro Eduardo de Felício(1)

(1) Universidade Estadual de Campinas, Faculdade de Engenharia de Alimentos, Departamento de Tecnologia de Alimentos, Cidade Universitária Zeferino Vaz, s/n ${ }^{\circ}$ Caixa Postal 6.121, CEP 13083-862 Campinas, SP, Brazil. E-mail: spflanzer@gmail.com, pedro.felicio@gmail.com

(2) Universidade Estadual de Campinas, Faculdade de Engenharia de Alimentos, Departamento de Alimentos e Nutrição, Cidade Universitária Zeferino Vaz, s/no Caixa Postal 6.121, CEP 13083-862 Campinas, SP, Brazil.

E-mail: carolinalugnani@gmail.com

$\bowtie$ Corresponding author

Received

November 21, 2017

Accepted

October 16, 2018

How to cite

PFLANZER, S.B.; GOMES, C.L.; FELÍCIO, P.E. de. Delayed carcass chilling improves tenderness of the beef gluteus medius muscle. Pesquisa Agropecuária Brasileira, v.54, e00099, 2019. DOI: https://doi.org/10.1590/ S1678-3921.pab2019.v54.00099.

\section{Delayed carcass chilling improves tenderness of the beef gluteus medius muscle}

\begin{abstract}
The objective of this work was to evaluate the effects of a slower chilling rate on the physical traits of 14-day aged top sirloin (gluteus medius) from F1 Angus x Nellore young bulls. Slight and lean beef carcasses $(n=30)$ were split in half and selected for control $\left(2^{\circ} \mathrm{C}\right.$ for 24 hours) and treatment $\left(10^{\circ} \mathrm{C}\right.$ for 10 hours followed by $2^{\circ} \mathrm{C}$ for 14 hours). Carcass temperature and $\mathrm{pH}$ decline were monitored in the longissimus dorsi (LD). Sarcomere length, color, and instrumental tenderness (Warner-Bratzler shear force and Volodkevich bite jaws) were measured on the gluteus medius (GM). pH 6.0 was reached when the $\mathrm{LD}$ temperature was very low, $3^{\circ} \mathrm{C}$ for the control and $6^{\circ} \mathrm{C}$ for the treatment. Differences in color and cooking losses were not significant. A trend was noticed for shorter sarcomere length and greater Warner-Bratzler shear force in the GM control. However, a lower value for Volodkevich bite jaws was found in the GM subjected to the treatment. The cooling regimes adopted were not sufficiently different to cause changes in color traits; however, the slow chilling of carcass improved tenderness and can be a good alternative to produce high-value cuts.
\end{abstract}

Index terms: beef carcass, chilling rates, sarcomere length, top sirloin, Volodkevich.

\section{Resfriamento lento das carcaças melhora a maciez do músculo gluteus medius bovino}

Resumo - O objetivo deste trabalho foi avaliar os efeitos de uma taxa de resfriamento mais lenta sobre as características físico-químicas da alcatra $(M$. gluteus medius) de touros F1 Angus x Nelore, maturada por 14 dias. Carcaças leves e magras $(\mathrm{n}=30)$ foram divididas em meias carcaças e selecionadas para controle $\left(2^{\circ} \mathrm{C}\right.$ por 24 horas $)$ e tratamento $\left(10^{\circ} \mathrm{C}\right.$ por 10 horas seguido de $2^{\circ} \mathrm{C}$ por 14 horas). A temperatura das carcaças e a queda do $\mathrm{pH}$ foram monitorados no M. longissimus dorsi (LD). O comprimento do sarcômero, a cor e a maciez instrumentais (força de cisalhamento Warner-Bratzler e Volodkevich bite jaws) foram medidos no M. gluteus medius (GM). O pH 6,0 foi atingido quando a temperatura do $\mathrm{LD}$ estava muito baixa, $3^{\circ} \mathrm{C}$ para o controle e $6^{\circ} \mathrm{C}$ para o tratamento. Diferenças na cor e perdas de cozimento não foram significativas. Uma tendência foi notada para menor comprimento do sarcômero e maior força de cisalhamento Warner-Bratzler no GM controle. No entanto, foi encontrado menor valor de Volodkevich bite jaws no GM submetido ao tratamento. Os regimes de resfriamento adotados não foram suficientemente diferentes para causar mudanças nos parâmetros de cor; porém, o resfriamento lento da carcaça melhorou a maciez e pode ser uma boa opção para produzir cortes de alto valor.

Termos para indexação: carcaça bovina, taxa de resfriamento, comprimento de sarcômero, alcatra, Volodkevich. 


\section{Introduction}

Consumer expectations of acceptable beef are one of the most crucial factors affecting the meat supply chain. When buying meat, they take into account color, amount of visible fat, price, and cut, and, when consuming it, tenderness, flavor, and juiciness (Robbins et al., 2003).

In fully developed meat markets, the beef top sirloin, known as "alcatra" in Brazil, is a cut of highly acceptable appearance, which is suitable for grilling, roasting or frying. However, it is rarely the first option in the retail market or restaurants, and it is usually sold as a cost-effective alternative. According to some authors, this cut, which is mainly formed by the gluteus medius (GM), has problems related to the consistency of palatability traits, as tenderness and juiciness (McKeith et al., 1981; Wheeler et al., 1990; Neely et al., 1998; Savell et al., 1999).

In postmortem muscles, the degree of rigor shortening and toughening depends largely on cooling temperature. Cold shortening, the rapid chilling of beef carcasses immediately after slaughter, has been intensively used by the meat industry due to its favorable influence on meat weight loss and storage life (James \& Bailey, 1986); however, it has negative impacts on the quality of the consumed meat, becoming more severe with decreasing temperatures (Locker \& Hagyard, 1963). Simmons et al. (2008) suggested that toughness by cold shortening could be related to a delayed aging due to fast chilling.

The effects of early-postmortem chilling rate on beef quality have been shown in several research works, particularly regarding the longissimus dorsi (Lochner et al., 1980; Marsh et al., 1981; Koh et al., 1987; Olsson et al., 1994; Rhee \& Kim, 2001; Sørheim et al., 2001; Hannula \& Puolanne, 2004; Yu et al., 2008; Wolcott et al., 2009). This type of information, however, is not easily available for the GM. Stolowski et al. (2006) reported that temperature and $\mathrm{pH}$ decline were muscle dependent and that, of the evaluated beef muscles, the GM, electrically stimulated or not, had the fastest rate of $\mathrm{pH}$ decline and highest temperatures during chilling, making it more tender than the others. This seems to be the case for heavier and fatter top sirloins, highly demanded by the "churrascarias" (barbecuestyle restaurants) in Brazil, but not for lighter and leaner cuts, currently more frequent.
The obtained results are indicative that cooling carcasses too slowly or too quickly can damage meat quality. Therefore, special care must be taken to ensure that the cooling process be favorable to all aspects regarding quality and safety in meat production (Braden, 2013).

The objective of this work was to evaluate the effects of a slower chilling rate on the physical traits of 14-day aged top sirloin from F1 Angus x Nellore young bulls.

\section{Materials and Methods}

Thirty F1 Angus x Nellore young bulls of approximately 13 months of age and $440 \mathrm{~kg}$ live weight were selected for this experiment out of 200 heads of cattle that had been raised on a feedlot for 107 days. The animals were slaughtered at a commercial beef plant in the municipality of Lins, in the state of São Paulo, Brazil. Pre-slaughtering handling was carried out according to good animal welfare practices, and slaughtering procedures followed the regulation for sanitary and industrial inspection of products of animal origin (Brasil, 1997). All carcasses were visually classified for fatness and weighed on the kill floor after kidney knob, channel, and inguinal fat removal. Average hot carcass weight was $240 \mathrm{~kg}$, and fatness was slight (1-3-mm fat on the twelfth rib). Half carcasses were used: the right sides, as a control subjected to conventional chilling; and the left ones, for a treatment with a distinct chilling rate. The half carcasses were moved into a chilling room within 30 min of slaughter, and this time was established as the 0 hour postmortem.

Control half carcasses were chilled according to the system used in modern packing plants, where a cooler is programmed to maintain constant air temperature at $2^{\circ} \mathrm{C}$ for 24 hours. For the treatment half carcasses, another cooler was programmed for an initial temperature of $10^{\circ} \mathrm{C}$ for the first 10 hours, and then the temperature was adjusted to $2^{\circ} \mathrm{C}$ for 14 hours.

Half carcass temperature and $\mathrm{pH}$ were manually monitored in the longissimus dorsi (LD), at the last two ribs, using the LoT406-M6-DXK-57/25 portable pH meter (Mettler Toledo Ind. e Com. Ltda., Barueri, SP, Brazil) with electrode and temperature probe, which was inserted approximately $5 \mathrm{~cm}$ deep, at 4, 7, 9, and 11 hours postmortem. 
$\mathrm{pH}$ and temperature were determined in the Longissimus muscle because these traits are always measured in this position in the meat industry. However, since, in the present study, the aim was to evaluate the quality of another muscle, the Longissimus was considered as the reference to monitor $\mathrm{pH}$ and temperature decline.

At 24 hours postmortem, the boneless top sirloin (MLA, 2003) of each half carcass was completely trimmed, skinned, and vacuum packaged in highbarrier Cryovac bags (Sealed Air: Food Care, Charlotte, NC, USA). These cuts were aged for 14 days, frozen at $-18^{\circ} \mathrm{C}$, and transported to the meat laboratory at Universidade Estadual de Campinas for analysis.

Later, meat cuts were thawed at $4^{\circ} \mathrm{C}$, and divided in two portions of $11 \mathrm{~cm}$. Measurements of $\mathrm{pH}$, sarcomere length, instrumental color, and shear force were taken. A total of $3 \mathrm{~g}$ muscle were homogenized in $20 \mathrm{~mL}$ distilled water for $15 \mathrm{~s}$ to determine $\mathrm{pH}$, which was obtained three times using the DM-22 $\mathrm{pH}$ meter (Digmed: Analytical Instrumentation, São Paulo, SP, Brazil) with a combined glass electrode.

Color was measured using the $\mathrm{L}^{*}, \mathrm{a}^{*}$, and $\mathrm{b}^{*}$ color space (also referred to as the CIELAB color space) in three positions in the middle of each GM half carcass, after a 30 min bloom time at $4^{\circ} \mathrm{C}$, using the CM-508d portable spectrophotometer (Konica Minolta Sensing Americas, Ramsey, NJ, USA) and the MiniScan XE (Hunter Associates Laboratory, Inc., Reston, VA, USA) with the illuminant $\mathrm{D}-65,10^{\circ} \mathrm{C}$ standard observer angle, and an aperture size of $3.5 \mathrm{~cm}$. The unit was calibrated using a black and a white standard plate, as specified by International Commission on Illumination (CIE, 1986).

GM sarcomere length was determined by the neon-laser diffraction method described by Cross et al. (1981), modified to evaluate a fresh piece of meat $(0.5 \times 0.5 \mathrm{~cm} \times 100 \mu \mathrm{m})$ removed parallel to the orientation of the muscle fibers. This piece was placed on microscope slides with cover slips and exposed to the 155SL helium-neon laser beam (Spectra-Physics, Santa Clara, CA, USA) of $632.8 \mathrm{~nm}$. The lengths of ten diffraction patterns from each sample were measured, and sarcomere length was determined by averaging these measurements.

Each middle sample of the GM was weighed (approximately $400 \mathrm{~g}$ ), and then six samples were cooked at a time in a Série $8-4000 \mathrm{~W}$ conventional oven (Imeque, Alto da Lapa, SP, Brazil), equipped with upper and lower electrical resistances. The oven was preheated with a thermostat adjusted to $170^{\circ} \mathrm{C}$, and each roast was placed on a metal rack over an aluminum tray. Thermocouples were used to individually monitor the internal temperatures of the roasts, which were removed from the oven when they reached the internal temperature of $71^{\circ} \mathrm{C}$ (AMSA, 1995).

After cooking, the roasts were weighed to calculate cooking losses and then were kept at room temperature for 2 hours, packed in plastic bags, and chilled at $4^{\circ} \mathrm{C}$ overnight. Cooked samples were used to measure instrumental tenderness by Warner-Bratzler shear force (WBSF) and Volodkevich bite jaws.

Three $1.27-\mathrm{cm}$ cores were taken from two $2.5-\mathrm{cm}$ thick slices, and three $1 \times 1-\mathrm{cm}$ parallelepiped samples were cut parallel to the muscle fibers. Each core and sample were sheared once in the perpendicular direction of the muscle fibers using the TA-XT2i texture meter (Texture Technologies Corp. and Stable Micro Systems, Ltd. Hamilton, MA, USA) equipped with a 1.06-mm thick Warner-Bratzler blade or Volodkevich bite jaws, respectively.

Data, including basic statistics and tables, were analyzed using the Statistica, version 7.0, software (TIBCO Software Inc., Palo Alto, CA, USA), in order to determine means, standard errors, correlation coefficients, and t-test for dependent samples to compare treatment means. Results were considered significant at $5 \%$ probability.

\section{Results and Discussion}

In the LD, temperature showed a fast drop in the first 4 hours of chilling, for both control and treatment half carcasses, reaching $14.4^{\circ} \mathrm{C}$. At 7 hours of chilling, the temperature of the control was already $8^{\circ} \mathrm{C}$; however, that of the treatment half carcasses, reached $11^{\circ} \mathrm{C}$. At 9 hours, the temperature of the control was $6^{\circ} \mathrm{C}$, but it remained the same as at 7 hours for the treatment half carcasses. At 11 hours postmortem, temperature was already below $4^{\circ} \mathrm{C}$ and a little above $6^{\circ} \mathrm{C}$ in the control and treatment half carcasses, respectively. Therefore, control and treatment means differed $(p<0.05)$ at 7,9 , and 11 hours (Figure 1). Although the muscle chilling rate often influences the glycolytic rate (Pike et al., 1993; Yu et al., 2008), this was not observed in the 
present study since differences in LD temperature were slight.

The $\mathrm{pH}$ means of $6.62,6.29,6.23$, and 6.04 were not different ( $\mathrm{p}>0.05)$ at $4,7,9$, and 11 hours postmortem, respectively (Figure 1). Prado \& Felício (2010) also found no difference in the $\mathrm{pH}$ decline curve when studying conventional and slow-air and spray chilling. However, Mohrhauser et al. (2014) reported that delayed chilling caused a faster $\mathrm{pH}$ decline, resulting in lower $\mathrm{pH}$ values at 6,12 , and 24 hours. The same trend was verified by $\mathrm{Li}$ et al. (2012).

Measurements of $\mathrm{pH}$ at 48 hours showed no difference between the control and treatment half carcasses $(p>0.05 ; 5.54)$. This is in alignment with other researchers who found no significant differences in $\mathrm{pH}$ values at 24 or 48 hours due to cooling rates (Koh et al., 1987; White et al., 2006; Kahraman et al., 2011, 2014; Li et al., 2012).

$\mathrm{pH} 6.0$ was reached at 11 hours postmortem when the LD temperature was below 7 and $4^{\circ} \mathrm{C}$, for the treatment and control half carcasses, respectively, which can be interpreted as a fall into the cold shortening zone of the superficial muscles of both carcass sides (Locker \& Hagyard, 1963; Bendall, 1973; Olsson et al., 1994).
No significant differences were observed between the control and treatment means in the GM regarding $\mathrm{L}^{*}, \mathrm{a}^{*}, \mathrm{~b}^{*}$, and Chroma values (Table 1), which is in agreement with the results of Yu et al. (2008) and Mao et al. (2012) for the longissimus lumborum (LL), but differs from those of Farouk \& Lovatt (2000) for the Semitendinosus and Biceps femoris, and of Janz et al. (2000) for the LL, who reported higher $L^{*}, a^{*}$, and $b^{*}$ values with increasing rigor temperature. Young et al. (1999) concluded that beef going into rigor at $9^{\circ} \mathrm{C}$ had the best bloomed color at 2 and 8 weeks of aging; however, in the present study, no color difference was detected at 14 days of aging. The obtained results suggest that the differences between the two cooling regimes evaluated here may have not been great enough to cause any effects on instrumental color.

There were no significant differences regarding the means of sarcomere length for the GM control $(1.61 \pm 0.10 \mu \mathrm{m})$ and treatment $(1.65 \pm 0.07 \mu \mathrm{m})$ (Table 2). The average sarcomere length of $1.63 \mu \mathrm{m}$ for the GM in the present study was similar to that of $1.66 \mu \mathrm{m}$ reported by Rhee et al. (2004), but notably shorter than those of 1.90, 1.91, and $1.77 \mu \mathrm{m}$, respectively, obtained by McKeith et al. (1985), Harris et al. (1992), and

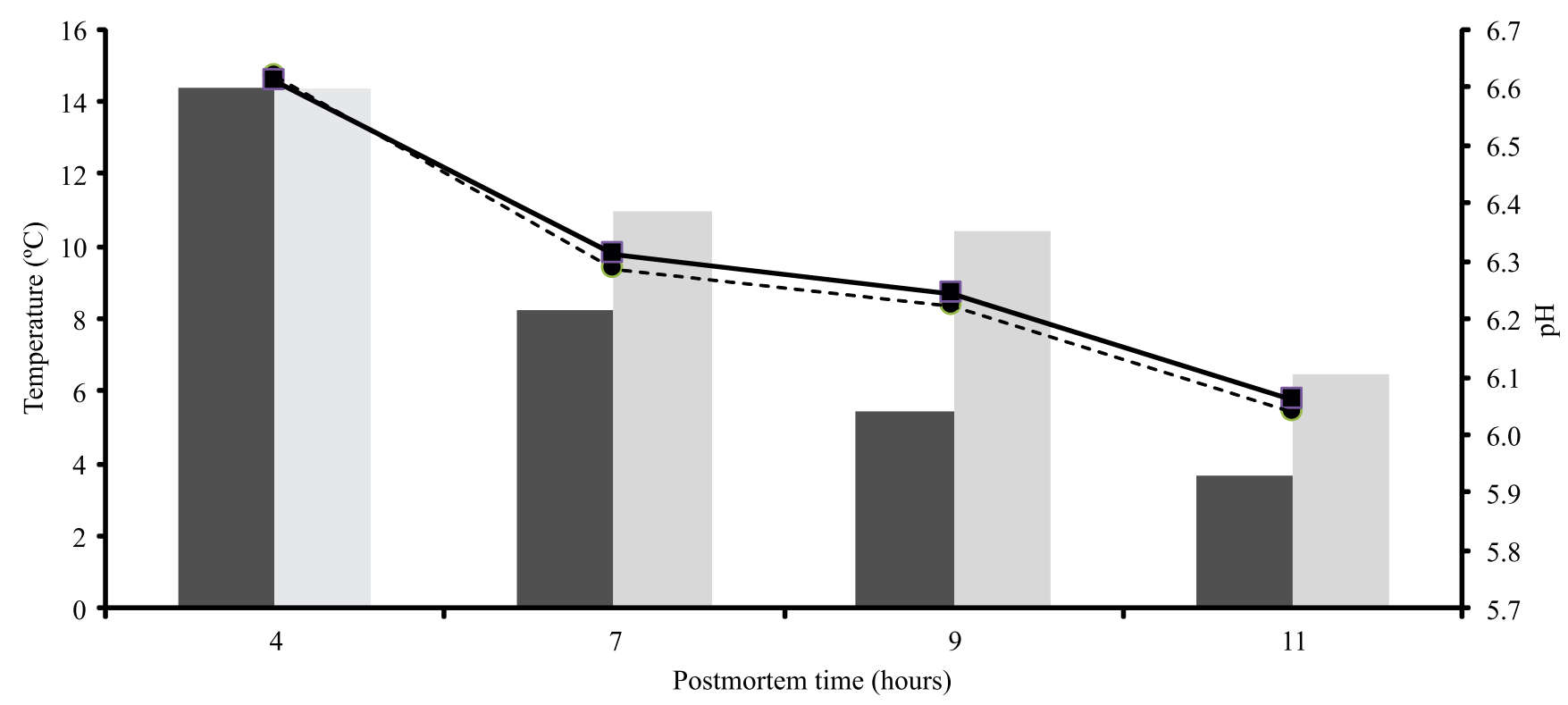

Control temperature $\quad$ Treatment temperature $\quad \ldots--$ Control pH

Figure 1. Temperature and $\mathrm{pH}$ decline of the control and treatment of Longissimus muscle half carcasses during chilling. Control, constant air temperature of $2^{\circ} \mathrm{C}$ for 24 hours; and Treatment, initial temperature of $10^{\circ} \mathrm{C}$ for the first 10 hours followed by $2^{\circ} \mathrm{C}$ for 14 hours. 
Stolowski et al. (2006), and longer than those of 1.50 and $1.58 \mu \mathrm{m}$ by King et al. (2009a, 2009b).

The means found for sarcomere length in the present study are indicative that the GM, subjected to both the treatment and control, likely suffered cold shortening, since it was much shorter than those described by McKeith et al. (1985), Harris et al. (1992), and Stolowski et al. (2006). Moreover, the chilling rate was too fast, because, at 11 hours postmortem, the LD temperature was below $7^{\circ} \mathrm{C}$, which can be interpreted as a fall into the cold shortening zone for superficial muscles, as the GM (Locker \& Hagyard, 1963; Bendall, 1973; Olsson et al., 1994).

Rhee et al. (2004) reported an average range of 1.3 $\mu \mathrm{m}(1.6-2.9 \mu \mathrm{m})$ for sarcomere length between 11 muscles. The Psoas major had the longest sarcomere length, and the GM the shortest. According to these authors, there is a high degree of variation in sarcomere length both among and within GM steaks. However, Hostetler et al. (1972) found a mean sarcomere length of $2.0 \mu \mathrm{m}$ for the GM in a condition of supposedly high fatness (only shown in pictures), obtaining sarcomere measurements of $\geq 1.9 \mu \mathrm{m}$ for all ten studied muscles.

It should be noted that sarcomere shortening can be reduced by changing the way the carcass is suspended. Hip suspension or tenderstretch results in a natural position of the muscles and keeps sarcomeres longer, which improves meat tenderness (Ahnström et al., 2012).

The results for cooking losses, Volodkevich bite jaws, and WBSF for the GM are shown in Table 2. There were no differences for means of cooking losses between cooling regimes, but there was a tendency for greater $(\mathrm{p}=0.08) \mathrm{WBSF}$ in the control $(53.32 \pm 14.73 \mathrm{~N})$

Table 1. Effect of cooling regime on the mean values of top sirloin (gluteus medius) instrumental color.

\begin{tabular}{lcccccc}
\hline $\begin{array}{l}\text { Instrumental } \\
\text { color }\end{array}$ & \multicolumn{2}{c}{ Control $(\mathrm{n}=30)^{(1)}$} & & \multicolumn{2}{c}{ Treatment $(\mathrm{n}=30)^{(2)}$} & \multirow{2}{*}{\begin{tabular}{c} 
P- \\
\cline { 2 - 3 } value $^{(3)}$
\end{tabular}} \\
\cline { 2 - 3 } & Means & SD & & Means & SD & \\
Lightness & 34.18 & 2.65 & & 34.24 & 2.89 & 0.83 \\
Redness & 18.01 & 1.34 & & 18.19 & 0.97 & 0.34 \\
Yellowness & 17.67 & 1.40 & & 17.80 & 1.21 & 0.46 \\
Chroma & 25.24 & 1.83 & & 25.45 & 1.46 & 0.40 \\
\hline
\end{tabular}

${ }^{(1)}$ Control, constant air temperature of $2^{\circ} \mathrm{C}$ for 24 hours. ${ }^{(2)}$ Treatment, initial temperature of $10^{\circ} \mathrm{C}$ for the first 10 hours followed by $2^{\circ} \mathrm{C}$ for 14 hours. SD, standard deviation. ${ }^{(3)}$ Statistical comparisons were performed using Student's t-test, at $5 \%$ probability. than in the treatment $(49.03 \pm 9.29 \mathrm{~N})$. Rhee et al. (2004) reported WBSF mean values of 42.22 to $44.59 \mathrm{~N}$, depending on the location within the GM. In addition, Honikel (2009) concluded that muscle $\mathrm{pH}$ at 24 hours postmortem can affect losses during cooking.

In this experiment, means of cooking losses were higher in both control and treatment half carcasses $(29.70 \pm 2.94$ and $28.94 \pm 2.08 \%)$, compared with the mean of $23.6 \%$ obtained by Rhee et al. (2004) for the same trait and muscle. However, Luchak et al. (1998) found a very similar mean of $29.9 \%$, when cooking steak at $74^{\circ} \mathrm{C}$ internal temperature, and George-Evins et al. (2004) reported 31\% cooking losses.

When measured by WBSF, no difference was observed for tenderness of the GM from carcasses that were slowly chilled $(49.03 \mathrm{~N})$, compared with the control ones $(53.32 \mathrm{~N})$. However, when determined by Volodkevich bite jaws, the treatment GM $(43.1 \mathrm{~N})$ was more tender than that the control one $(46.8 \mathrm{~N})$. According to Pomponio \& Ertbjerg (2012), calpastatin activity is lower at higher temperatures, which can contribute to increase tenderness of beef subjected to slow chilling processes.

In the present study, the GM did not show good enough WBSF values, with an average of $51.2 \mathrm{~N}$, probably due to the short sarcomere lengths in both the control and treatment half carcasses. Trying to investigate the impacts of shorter sarcomeres on GM tenderness, Hostetler et al. (1972) observed that WBSF, converted to Newton, was $48.02 \mathrm{~N}$ when the carcass was hung by the Achilles tendon, but $36.26 \mathrm{~N}$ when

Table 2. Effect of cooling regime on the mean values of top sirloin (gluteus medius) ultimate $\mathrm{pH}$, sarcomere length, cooking loss, and instrumental tenderness analysis by Warner-Bratzler shear force (WBSF) and Volodkevich bite jaws (VBJ).

\begin{tabular}{lcccccc}
\hline Characteristic & \multicolumn{2}{c}{ Control $(\mathrm{n}=30)^{(1)}$} & & \multicolumn{2}{c}{ Treatment $(\mathrm{n}=30)^{(2)}$} & \multirow{2}{\text{P-}}{} \\
\cline { 2 - 3 } & Means & SD & & Means & SD & value $^{(3)}$ \\
\hline Sarcomere $(\mu \mathrm{m})$ & 1.61 & 0.10 & & 1.65 & 0.07 & 0.08 \\
pH (48 hours) & 5.53 & 0.12 & & 5.56 & 0.12 & 0.10 \\
Cooking loss $(\%)$ & 29.70 & 2.94 & & 28.94 & 2.08 & 0.17 \\
WBSF (N) & 53.32 & 14.74 & & 49.03 & 9.29 & 0.08 \\
VBJ (N) & 46.8 & 13.2 & & 43.1 & 12.1 & 0.02 \\
\hline
\end{tabular}

${ }^{(1)}$ Control, constant air temperature of $2^{\circ} \mathrm{C}$ for 24 hours. (2)Treatment, initial temperature of $10^{\circ} \mathrm{C}$ for the first 10 hours followed by $2^{\circ} \mathrm{C}$ for 14 hours. SD, standard deviation. ${ }^{(3)}$ Statistical comparisons were performed using Student's t-test, at 5\% probability. 
hung by the pelvic bone due to muscle stretching, which increased sarcomere length from 2.0 to $2.8 \mu \mathrm{m}$.

Derbyshire et al. (2007) found that sarcomere lengths were significantly increased by hip suspension, but were not affected by electrical stimulation. However, both of these treatments were able to improve meat tenderness, showing that other traits, besides sarcomere length, can affect tenderness.

McKeith et al. (1985), aiming to prevent cold shortening at $\mathrm{pH} 5.5$ and $15.5^{\circ} \mathrm{C}$, obtained $1.90 \mu \mathrm{m}$ for sarcomere length and $34.10 \mathrm{~N}$ for WBSF for the GM. Harris et al. (1992) reported similar sarcomere length of $1.91 \mu \mathrm{m}$ and WBSF of $41.25 \mathrm{~N}$. According to George-Evins et al. (2004) and Gruber et al. (2006), the WBSF of the GM can improve the quality grade (carcass fatness) used to rank meat by United States Department of Agriculture; for example, for 14 dayaged GM, these authors found values of 44.39 and $53.99 \mathrm{~N}$ for Choice and Select grades, respectively. In Brazil, a current commercial practice is to select top sirloin cuts out of heavy and fat carcasses for the "churrascarias".

\section{Conclusion}

The slower cooling conditions in the first 10 hours postmortem do not affect top sirloin (gluteus medius) color, but are effective for improvement of instrumental tenderness, adding more value to this cut.

\section{Acknowledgments}

To Conselho Nacional de Desenvolvimento Científico e Tecnológico $(\mathrm{CNPq}$, process number 140208/2008-9), for doctorate scholarship; to Pecuária Damha, for donating the meat cuts for the study; and to Frigorífico Bertin Ltda., for allowing data and sample collection.

\section{References}

AHNSTRÖM, M.L.; HUNT, M.C.; LUNDSTRÖM, K. Effect of pelvic suspension of beef carcasses on quality and physical traits of five muscles from four gender-age groups. Meat Science, v.90, p.528-535, 2012. DOI: https://doi.org/10.1016/j. meatsci.2011.09.003.

AMSA. American Meat Science Association. Research guidelines for cookery, sensory evaluation and tenderness measurements of fresh meat. Chicago, 1995.
BENDALL, J.R. The biochemistry of rigor mortis and cold contracture. In: EUROPEAN MEETING OF MEAT RESEARCH WORKERS, 19., 1973, Paris. Proceedings. Paris, 1973. p.1-27.

BRADEN, K.W. Converting muscle to meat: the physiology of rigor. In: KERTH, C.R. (Ed.). The science of meat quality. Iowa: J. Wiley \& Sons, 2013. p.79-97. DOI: https://doi.org/10.1002/9781118530726.ch5.

BRASIL. Ministério da Agricultura, Pecuária e Abastecimento. Regulamento da inspeção industrial e sanitária de produtos de origem animal [e] legislação inclusa. Brasília, 1997.

CIE. International Commission on Illumination. CIE 15.2: colorimetry. $2^{\text {nd }}$ ed. Vienna, 1986. 85p.

CROSS, H.R.; WEST, R.L.; DUTSON, T.R. Comparison of methods for measuring sarcomere length in beef semitendinosus muscle. Meat Science, v.5, p.261-266, 1981. DOI: https://doi.org/10.1016/0309-1740(81)90016-4.

DERBYSHIRE, W.; LUES, J.F.R.; JOUBERT, G.; SHALE, K.; JACOBY, A.; HUGO, A. Effect of electrical stimulation, suspension method and aging on beef tenderness of the Bonsmara breed. Journal of Muscle Foods, v.18, p.207-225, 2007. DOI: https://doi.org/10.1111/j.1745-4573.2007.00078.x.

FAROUK, M.M.; LOVATT, S.J. Initial chilling rate of pre-rigor beef muscles as an indicator of colour of thawed meat. Meat Science, v.56, p.139-144, 2000. DOI: https://doi.org/10.1016/ S0309-1740(00)00031-0.

GEORGE-EVINS, C.D.; UNRUH, J.A.; WAYLAN, A.T.; MARSDEN, J.L. Influence of quality classification, aging period, blade tenderization, and endpoint cooking temperature on cooking characteristics and tenderness of beef gluteus medius steaks. Journal of Animal Science, v.82, p.1863-1867, 2004. DOI: https://doi.org/10.2527/2004.8261863x.

GRUBER, S.L.; TATUM, J.D.; SCANGA, J.A.; CHAPMAN, P.L.; SMITH, G.C.; BELK, K.E. Effects of postmortem aging and USDA quality grade on Warner-Bratzler shear force values of seventeen individual beef muscles. Journal of Animal Science, v.84, p.3387-3396, 2006. DOI: https://doi.org/10.2527/jas.2006194.

HANNULA, T.; PUOLANNE, E. The effect of cooling rate on beef tenderness: the significance of $\mathrm{pH}$ at $7^{\circ} \mathrm{C}$. Meat Science, v.67, p.403-408, 2004. DOI: https://doi.org/10.1016/j. meatsci.2003.11.012.

HARRIS, J.J.; MILLER, R.K.; SAVELL, J.W.; CROSS, H.R.; RINGER, L.J. Evaluation of the tenderness of beef top sirloin steaks. Journal of Food Science, v.57, p.6-9, 1992. DOI: https://doi.org/10.1111/j.1365-2621.1992.tb05412.x.

HONIKEL, K.O. Moisture and water-holding capacity. In: NOLLET, L.M.L.; TOLDRA, F. (Ed.). Handbook of muscle foods analysis. Boca Raton: CRC Press, 2009. p.315-334.

HOSTETLER, R.L.; LINK, B.A.; LANDMANN, W.A.; FITZHUGH JR, H.A. Effect of carcass suspension on sarcomere length and shear force of some major bovine muscles. Journal of Food Science, v.37, p.132-135, 1972. DOI: https://doi.org/10.1111/j.1365-2621.1972.tb03402.x. 
JAMES, S.J.; BAILEY, C. Temperature changes, weight loss and product loads during beef chilling. In: PROGRESS ET DÉVELOPPEMENTS DU TRAITEMENT FRÍGORIFIQUE DE LA VIANDE RÉFRIGÉRÉE. Procédure. Paris: International Institute of Refrigeration, 1986. p.105-114.

JANZ, J.A.M.; AALHUS, J.L.; PRICE, M.A.; SCHAEFER, A.L. The influence of elevated temperature conditioning on bison (Bison bison bison) meat quality. Meat Science, v.56, p.279-284, 2000. DOI: https://doi.org/10.1016/S0309-1740(00)00054-1.

KAHRAMAN, T.; BAYRAKTAROGLU, A.G.; BOSTAN, K.; KOÇAK, Ö. Effects of electrical stimulation on quality and microstructure of rapid chilled beef carcasses. Kafkas Üniversitesi Veteriner Fakültesi Dergisi, v.17, p.291-295, 2011. DOI: https://doi.org/10.9775/kvfd.2010.3442.

KAHRAMAN, T.; GHASSAN, I.; BINGÖL, E.B.; DÜMEN, E.; GÖKSOY, E.Ö.; BÜYÜKÜNAL, S.K. Effect of rapid chilling and pelvic suspension on meat quality of Longissimus dorsi muscle of lamb. Kafkas Üniversitesi Veteriner Fakültesi Dergisi, v.20, p.697-701, 2014. DOI: https://doi.org/10.9775/kvfd.2014.10945.

KING, D.A.; SHACKELFORD, S.D.; WHEELER, T.L.; PFEIFFER, K.D.; MEHAFFEY, J.M.; MILLER, M.F.; NICKELSON, R.; KOOHMARAIE, M. Consumer acceptance and steak cutting yields of beef top sirloin and knuckle subprimals. Meat Science, v.83, p.782-787, 2009a. DOI: https://doi.org/10.1016/j.meatsci.2009.08.021.

KING, D.A.; WHEELER, T.L.; SHACKELFORD, S.D.; KOOHMARAIE, M. Comparison of palatability characteristics of beef gluteus medius and triceps brachii muscles. Journal of Animal Science, v.87, p.275-284, 2009 b. DOI: https://doi.org/10.2527/jas.2007-0809.

KOH, K.C.; BIDNER, T.D.; MCMILLIN, K.W.; HILL, G.M. Effects of electrical stimulation and temperature on beef quality and tenderness. Meat Science, v.21, p.189-201, 1987. DOI: https://doi.org/10.1016/0309-1740(87)90089-1.

LI, K.; ZHANG, Y.; MAO, Y.; CORNFORTH, D.; DONG, P.; WANG, R.; ZHU, H.; LUO, X. Effect of very fast chilling and aging time on ultra-structure and meat quality characteristics of Chinese Yellow cattle M. Longissimus lumborum. Meat Science, v.92, p.795-804, 2012. DOI: https://doi.org/10.1016/j. meatsci.2012.07.003

LOCHNER, J.V.; KAUFFMAN, R.G.; MARSH, B.B. Earlypostmortem cooling rate and beef tenderness. Meat Science, v.4, p.227-241, 1980. DOI: https://doi.org/10.1016/03091740(80)90051-0.

LOCKER, R.H.; HAGYARD, C.J. A cold shortening effect in beef muscles. Journal of the Science of Food and Agriculture, v.14, p.787-793, 1963. DOI: https://doi.org/10.1002/jsfa.2740141103.

LUCHAK, G.L.; MILLER, R.K.; BELK, K.E.; HALE, D.S.; MICHAELSEN, S.A.; JOHNSON, D.D.; WEST, R.L.; LEAK, F.W.; CROSS, H.R.; SAVELL, J.W. Determination of sensory, chemical and cooking characteristics of retail beef cuts differing in intramuscular and external fat. Meat Science, v.50, p.55-72, 1998. DOI: https://doi.org/10.1016/S0309-1740(98)00016-3.

MAO, Y.; ZHANG, Y.; LIANG, R.; REN, L.; ZHU, H.; LI, K.; ZHU, L.; LUO, X. Effect of rapid chilling on beef quality and cytoskeletal protein degradation in M. longissimus of Chinese Yellow crossbred bulls. Asian-Australasian Journal of Animal Sciences, v.25, p.1197-1204, 2012. DOI: https://doi.org/10.5713/ ajas.2012.12055.

MARSH, B.B.; LOCHNER, J.V.; TAKAHASHI, G.; KRAGNESS, D.D. Effects of early post-mortem $\mathrm{pH}$ and temperature on beef tenderness. Meat Science, v.5, p.479-483, 1981. DOI: https://doi.org/10.1016/0309-1740(81)90046-2.

MCKEITH, F.K.; DEVOL, D.L.; MILES, R.S.; BECHTEL, P.J.; CARR, T.R. Chemical and sensory properties of thirteen major beef muscles. Journal of Food Science, v.50, p.869-872, 1985. DOI: https://doi.org/10.1111/j.1365-2621.1985.tb12968.x.

MCKEITH, F.K.; SAVELL, J.W.; SMITH, G.C. Tenderness improvement of the major muscles of the beef carcass by electrical stimulation. Journal of Food Science, v.46, p.1774-1776, 1981. DOI: https://doi.org/10.1111/j.1365-2621.1981.tb04482.x.

MLA. Meat \& Livestock Australia. Value adding: muscle seaming \& cooking methods. Austrália, 2003.

MOHRHAUSER, D.A.; LONERGAN, S.M.; HUFFLONERGAN, E.; UNDERWOOD, K.R.; WEAVER, A.D. Calpain-1 activity in bovine muscle is primarily influenced by temperature, not $\mathrm{pH}$ decline. Journal of Animal Science, v.92, p.1261-1270, 2014. DOI: https://doi.org/10.2527/jas.2013-7270.

NEELY, T.R.; LORENZEN, C.L.; MILLER, R.K.; TATUM, J.D.; WISE, J.W.; TAYLOR, J.F.; BUYCK, M.J.; REAGAN, J.O.; SAVELL, J.W. Beef customer satisfaction: role of cut, USDA quality grade, and city on in-home consumer ratings. Journal of Animal Science, v.76, p.1027-1033, 1998. DOI: https://doi.org/10.2527/1998.7641027x.

OLSSON, U.; HERTZMAN, C.; TORNBERG, E. The influence of low temperature, type of muscle and electrical stimulation on the course of rigor mortis, ageing and tenderness on beef muscles. Meat Science, v.37, p.115-131, 1994. DOI: https://doi.org/10.1016/0309-1740(94)90149-X.

PIKE, M.M.; RINGKOB, T.P.; BEEKMAN, D.D.; KOH, Y.O.; GERTHOFFER, W.T. Quadratic relationship between early-post-mortem glycolytic rate and beef tenderness. Meat Science, v.34, p.13-26, 1993. DOI: https://doi.org/10.1016/03091740(93)90015-A.

POMPONIO, L.; ERTBJERG, P. The effect of temperature on the activity of $\mu$-and $\mathrm{m}$-calpain and calpastatin during post-mortem storage of porcine longissimus muscle. Meat Science, v.91, p.5055, 2012. DOI: https://doi.org/10.1016/j.meatsci.2011.12.005.

PRADO, C.S.; FELÍCIO, P.E. de. Effects of chilling rate and spray-chilling on weight loss and tenderness in beef strip loin steaks. Meat Science, v.86, p.430-435, 2010. DOI: https://doi.org/10.1016/j.meatsci.2010.05.029.

RHEE, M.S.; KIM, B.C. Effect of low voltage electrical stimulation and temperature conditioning on postmortem changes in glycolysis and calpains activities of Korean native cattle (Hanwoo). Meat Science, v.58, p.231-237, 2001. DOI: https://doi.org/10.1016/S0309-1740(00)00155-8.

RHEE, M.S.; WHEELER, T.L.; SHACKELFORD, S.D.; KOOHMARAIE, M. Variation in palatability and 
biochemical traits within and among eleven beef muscles. Journal of Animal Science, v.82, p.534-550, 2004. DOI: https://doi.org/10.2527/2004.822534x.

ROBBINS, K.; JENSEN, J.; RYAN, K.J.; HOMCO-RYAN, C.; MCKEITH, F.K.; BREWER, M.S. Consumer attitudes towards beef and acceptability of enhanced beef. Meat Science, v.65, p.721729, 2003. DOI: https://doi.org/10.1016/S0309-1740(02)00274-7.

SAVELL, J.W.; LORENZEN, C.L.; NEELY, T.R.; MILLER, R.K.; TATUM, J.D.; WISE, J.W.; TAYLOR, J.F.; BUYCK, M.J.; REAGAN, J.O. Beef customer satisfaction: cooking method and degree of doneness effects on the top sirloin steak. Journal of Animal Science, v.77, p.645-652, 1999. DOI: https://doi.org/10.2527/1999.773645x.

SIMMONS, N.J.; DALY, C.C.; CUMMINGS, T.L.; MORGAN, S.K.; JOHNSON, N.V.; LOMBARD, A. Reassessing the principles of electrical stimulation. Meat Science, v.80, p.110-122, 2008. DOI: https://doi.org/10.1016/j.meatsci.2008.05.006.

SØRHEIM, O.; IDLAND, J.; HALVORSEN, E.C.; FRØYSTEIN, T.; LEA, P.; HILDRUM, K.I. Influence of beef carcass stretching and chilling rate on tenderness of $m$. longissimus dorsi. Meat Science, v.57, p.79-85, 2001. DOI: https://doi.org/10.1016/S03091740(00)00079-6.

STOLOWSKI, G.D.; BAIRD, B.E.; MILLER, R.K.; SAVELL, J.W.; SAMS, A.R.; TAYLOR, J.F.; SANDERS, J.O.; SMITH, S.B. Factors influencing the variation in tenderness of seven major beef muscles from three Angus and Brahman breed crosses. Meat
Science, v.73, p.475-483, 2006. DOI: https://doi.org/10.1016/j. meatsci.2006.01.006.

WHEELER, T.L.; MILLER, R.K.; SAVELL, J.W.; CROSS, H.R. Palatability of chilled and frozen beef steaks. Journal of Food Science, v.55, p.301-304, 1990. DOI: https://doi.org/10.1111/j.1365-2621.1990.tb06748.x.

WHITE, A.; O'SUllivAN, A.; O’NEILl, E.E.; TROY, D.J. Manipulation of the pre-rigor phase to investigate the significance of proteolysis and sarcomere length in determining the tenderness of bovine M. longissimus dorsi. Meat Science, v.73, p.204-208, 2006. DOI: https://doi.org/10.1016/j.meatsci.2005.11.022.

WOLCOTT, M.L.; JOHNSTON, D.J.; BARWICK, S.A.; IKER, C.L.; THOMPSON, J.M.; BURROW, H.M. Genetics of meat quality and carcass traits and the impact of tenderstretching in two tropical beef genotypes. Animal Production Science, v.49, p.383-398, 2009. DOI: https://doi.org/10.1071/EA08275.

YOUNG, O.A.; PRIOLO, A.; SIMMONS, N.J.; WEST, J. Effects of rigor attainment temperature on meat blooming and colour on display. Meat Science, v.52, p.47-56, 1999. DOI: https://doi.org/10.1016/S0309-1740(98)00147-8.

YU, L.H.; LIM, D.G.; JEONG, S.G.; IN, T.S.; KIM, J.H.; AHN, C.N.; KIM, C.J.; PARK, B.Y. Effects of temperature conditioning on postmortem changes in physico-chemical properties in Korean native cattle (Hanwoo). Meat Science, v.79, p.64-70, 2008. DOI: https://doi.org/10.1016/j.meatsci.2007.07.033. 